\title{
Moroccan TV Programming in Ramadan: An Analysis of Gender Representations
}

\author{
Mohamed EL Kandoussi (PhD) \\ Moulay Ismail University, L’Ecole Supérieure de Technologie, \\ Meknès (ESTM), Morocco
}

doi: 10.19044/esj.2017.v13n8p121 URL:http://dx.doi.org/10.19044/esj.2017.v13n8p121

\begin{abstract}
The purpose of this article is to explore how gender representations are portrayed through the examination of the salient images and messages latent in a prime-time comic series entitled 'Kenza F'Douar' (Kenza in the village) that was aired during the holy month of Ramadan in 2014 on $2 \mathrm{M}$ which is a Moroccan state-owned television channel. The study adopts the textual representation approach and draws heavily on the critical discourse analysis. The findings point to the absence of a coherent and consistent policy by the domestic outlet towards the gender issue in the series. The paper also reveals that the gender representations as manifested in the program are not compatible with the institutional endeavor to counter the perpetuation of stereotypical portrayals on the national media.
\end{abstract}

Keywords: Gender, television, distribution, reality, representations

\section{Introduction}

Despite the boom in information and communication technologies, which has spawned a number of alluring tools, such as the Internet, tablets, and smart phones, few media analysts would agree that the medium of TV has been completely abandoned. Truly, its iron grip may have been loosened, but it still continues to occupy a central position as a socialization institution. In Morocco at least, the triumph of the little tube is primarily assigned to its ability to reach millions of homes and overcome barriers of illiteracy. Its presence as a commodity, which not only informs and entertains but also provides companionship and security, is unquestionable. Indeed, television is more than a simple means of mass communication. For several decades, this medium has been part and parcel of the enculturation and socialization process of many generations (Gerbner et al., 1986; 1994).

Each year, the holy month of Ramadan- when Muslims fast during daytime from sunrise to sunset- represents a 'precious' opportunity for 
domestic TV channels to reap enormous financial profit -through massive advertising- as millions of Moroccans gather around the breakfast meal to consume not only palatable food and drinks but also bulky fares of entertainment, mostly comic sitcoms and sensational soap-operas. This commonplace ritual that characterizes nearly all countries of the Arab world, has for many years been harshly criticized by many media analysts, religious clerics, academics, as well as education experts. It is not the intent of this paper, however, to mainly report these worries and concerns, but rather to see how gender representations are portrayed on the comic series of 'Kenza $F$ 'Douar' 'Kenza in the village' that was broadcast on the Moroccan domestic television channel 2M during the holy fasting month of Ramadanwhich is the ninth month in the Islamic lunar (hijri) calendar- which lasted from June 30 to July 29, 2014.

\section{Synopsis}

Before proceeding to the analysis of the research issue outlined above, a brief synopsis of the TV program under study is in order. 'Kenza $F$ 'Douar' (Kenza in the village) is a sitcom or a series that falls under the genre of social comedy. It was produced by $2 \mathrm{M}$ channel, directed by Hicham Laasri, and starred by Meriem Zaimi who had graduated from the 'High Institute of Dramatic Art and Cultural Animation’ in Rabat. The sitcom also featured several leading Moroccan actors and actresses, mainly Mohamed Bastaoui, Dounia Boutazout, Aziz Hattab, and Benaissa Jirari. This primetime program lasted thirty minutes -from 20:20 to 20:50- and was broadcast, all through Ramadan in 30 episodes. The sitcom recounts the story of a pretty and ambitious young urban girl, aged 33, named Kenza Berrada Bennani, who works for a highway construction company in Casablanca. She has recently been assigned the hard job of persuading the inhabitants of a small remote village, called 'Douar 360' to agree to the expropriation of a large part of their village to allow the company to complete the highway route. Her efforts meet with a firm resistance from most residents and she is thus obliged to stay with a local family. In so doing, she is exposed to a new different lifestyle and set of values.

\section{$2 \mathrm{M}$ in the media scenery}

My choice of the Moroccan local channel 2M as the locus of analysis is mainly attributable to its status as the second oldest TV channel in the history of the Moroccan audio-visual scenery -after Al Oula TV stationfollowing its genesis in 1989 as a cable pay channel. Unsurprisingly, then, this media outlet had for many years enjoyed a very large audience thanks to its deployment of hitherto some of the latest broadcasting technology, recruitment of qualified personnel, and the transmission of highly appealing 
and diverse programming though it had initially failed to entirely guarantee the coverage of all parts of the national territory. Over the last few years, however, and with the proliferation of a plethora of both domestic and freeto-air Arab satellite TV channels, 2M has ceased to occupy its central position as the elitist and liberal station that caters to the need of millions of avid Moroccan viewers. Much of the criticism centres on its inability to produce original and meaningful content that tackles real-life and timely issues and serves the public interest. The channel's overreliance on import material from Latin America and Turkey (Latino and Turkish soaps) is another major accusation levelled at the station.

As stated earlier, the bulk of the Moroccan local TV channels' financial resources in the holy month of Ramadan are devoted to producing entertainment programs that are assumed to reduce a long day's stress and tension. 2M station is no exception. These include, among others, sit-coms, hidden cameras, soap-operas, and locally-made movies and dramas. Because of their use of the local vernacular - the Moroccan Darija- which is intelligible to the predominant majority of Moroccans, sitcoms have regularly topped the viewer ratings in Ramadan for more than a decade, not only on $2 \mathrm{M}$ but also on the other major competitive national outlet, namely Al Oula.

\section{Rationale}

The choice of this sit-com owes its legitimacy to its large viewer ratings as a prime-time television program together with the torrents of public reactions reported on numerous blogs, Facebook fan pages, you-tube videos etc. Indeed, according to Maroc-métrie, which is a private company in charge of measuring the audiences of the various audiovisual media in a scientific and independent way, 'Kenza F' Douar' topped the ratings with 9.24 million spectators for the first episode (about 62\% of aggregate viewership) followed by 'Hidden camera' with 8.5 millions, then came the hilarious series ‘the couple’ with 8 million viewers (TelQuel, 2014).

One more motive for choosing to work on this issue relates to the current literature that seems to point to a shift from orthodox and rather conventional definitions of television exposure. Several contemporary have documented the scholarly attempts to redefine the notion because of its rather fluid and elusive nature. According to The Kaiser Family Foundation (2010), television consumption includes "live TV, recorded TV, DVDs viewed on TV or computers, and streamed or downloaded TV content viewed on a computer, cell phone or mp3 player.” Clearly, new information and communication technologies have considerably widened the accessibility of TV programming to consumers from across the social spectrum. Compared to the past, viewers can now consume more varied 
content, anytime and anywhere, using a number of devices, such as laptops and mobile phones.

\section{Scope and framework}

At the outset, it is interesting to recall to mind the fact that sex and gender as two distinct but quite interrelated concepts. Artz and Alladi (1991) offer clear and very insightful definitions of these multidimensional notions. For them, gender needs to be understood as a culturally constructed category which goes beyond but encompasses the biological category of sex, the social-psychological category of sex role, the psychological category of masculine and feminine identity, and the psycho-behavioral category of sexuality. In the marketing literature there has been a tendency to confuse these categories and a failure to appreciate their theoretical underpinnings (p. 1).

Interestingly, then, gender subsumes all expected and desired patterns of social behavior that pertain to both men and women and which are inculcated all through the socialization phases of an individual. Sex, however, refers to "the genetic and physiological characteristics and traits that indicate whether one is male or female.” (Goldberg; Lang \& Biasutti, 2005).

Hence, any analysis of gender representation in the media needs to adopt a well-established theoretical framework and clear operationalization measures of the major constructs. A number of studies have approached gender investigation using different frameworks and analytical tools. Importantly enough, though empirical research conducted on gender analysis of TV content only harkens back to the early seventies of the last century, it significantly cuts across a number of disciplines ranging from -amongst others- sociology, social criticism, feminist theory, to philosophy and mass communications (Artz \& Alladi, 1991). Given its interdisciplinary nature, this paper adopts the textual discourse analysis approach (Frey, Botan \& Kreps, 1999) and is also inspired by the seminal study undertaken by Smith and Cook (2008). In line with their analysis, gender representation entails the examination of five broad components, namely prevalence, occupational portrayal, hypersexualization, ethnicity and character drive.

\section{Representations and reality}

A significant way to assess the extent to which TV contributes to the overall national developmental strategy, that aims to establish social justice in which gender equity is a prime goal, is its ability to develop certain basic guidelines to ensure a 'fair' representativeness of the diverse social categories in its programming. Put differently, there needs to be a high concordance between the distribution of the characters in the show and the 
real-life proportions of the population segments and niches. Failure to do so may result in the cultivation of distorted perceptions about social reality. This assumption has been extensively discussed by many media models and theories, such as social learning theory, cultural imperialism paradigm, and the cultivation theory. The latter, which is in essence a theory of social control, is behind the elaboration of the concept of 'first order effects' that refers to the viewer's personal "estimates of real world occurrences of events and estimates of popular opinion distribution” (Rössler \& Brosins, 2001, p.149). The perceptions or general cognitions are not necessarily established or formed beliefs yet. A viewer may have developed a distorted estimation about the distribution of demographic features, the status of minority groups or the representation of criminals drawing on the world of TV (Potter \& Chang, 1990).

With reference to the program under analysis, the show features 04 leading females (67\%) compared to 08 leading male roles (33\%). Based on the Moroccan Census Bureau's statistics, women in Morocco account for $50.4 \%$ compared to $49.6 \%$ of men (Haut-commissariat, 1015).

Similarly, there seems to be a quasi-predominance of the 'white' skin characters in the series. Naturally, though a color-based census in Morocco is not legitimated -mainly for demographic, ethnic, historical, and religious grounds-, such disparity runs counter to common sense observation of the skin color spectrum distribution in the country. What is more, apart from very few actors -03- with a 'black-skin who are assigned minor and even humiliating roles like riding breathlessly two old bicycles to run the electric energy batteries of the local café, all the remaining leading roles are attributed to 'white' actors. On the face of it, this may sound pure coincidence. However, many media experts and human rights activists (Entman \& Rojecki, 2000; Jamieson, 1993; Lublin 1997, b) accuse such distribution of impartiality and connivance to exclude 'non-white' people from prominent roles not only from most media genres but also from important decision-making positions in mass media outlets with a view to perpetuating the hegemony of the 'socially advantaged' white elite. Such a claim may be readily dismissed by specialists, especially directors, who may simply assign this 'unfair' disproportion to professional reasons related to casting and the shortage in adequate profiles rather than acquiescing to the lobbying of marketers and powerful advertising mega-companies who may dictate the attributes and features of stardom as well as what constitutes fashion, style, and taste etc.

In the same vein, the sit-com does not generally adopt a socially realistic line in its treatment of the complex notions of religion and ideology. Morocco is an ethnically and culturally diverse country with a mosaic, rich and pluralistic culture. Though being largely a Muslim country, other 
religious minorities, mainly the Jews, account for about $0.1 \%$ of the national population (Pergola, 2012). Viewed from the lens of public service television framework (Habermas, 1992; McQuail, 2003), all social segments, ethnic groups and religious categories need, not only be catered to in terms of programming, but equally be involved in the production of media messages and images as they are considered 'full members' by virtue of their being 'tax payers'. Such reality is reflected at various levels including appearance and dress.

Indeed, thanks to the rising presence of females in the public sphere, and the growing power of women in mass media space, the Arab and Moroccan woman has managed to penetrate the various circles of decisionmaking in program design, production, and distribution. More specifically, she has succeeded to offset the patriarchic supremacy of her male counterpart as a movie or melodrama protagonist, news analyst and presenter as well as program animator (talk-show, reality TV, sports program etc.). This image has transcended the rather parochial view of the Moroccan TV presenter as a liberal and 'emancipated' woman to a new ideologicallymotivated outlook that accommodates the 'other' women, namely those who get dressed in a traditional, conservative or even 'fundamentalist' fashion like wearing the head-scarf or hijab. However, this dimension of 'appearance and dress' seems to be unfairly wanting across the different genres on the Moroccan TV scenery at least. Surprisingly, all through the 30 episodes of the series, there featured no veiled woman or one that represents allegedly 'hard-line' Islamic faith, which is naturally in complete juxtaposition to a massive presence of hijab-dressed females in public space (schools, universities, various occupations and settings). Skeptics may believe that this flagrant imbalance may be largely owed to the significant and pervasive impact that Ramadan programming, in particular, could have on viewers for an extended period of time. Gauntlet (2008) explains how religion and ideology are carefully approached in most media policies. For him, religious faiths which tell people to behave in particular traditional ways, which previously would have been politely ignored as rather difficult and backward, are now accorded somewhat more respect by news and current affairs media; but subtly shunned in comedy and drama productions (p. 4).

\section{Ethnicity, class, and power}

One of the interesting ways to demystify how mass media in general and broadcast TV in particular conspire to define social categories and develop cognitive schemes is by examining the interplay between the constructs of ethnicity, class, and power. In other words, it is only by analyzing the institutional guidelines and production orientations of the national mass media that we can arrive at an understanding of the dominant 
ideological practices. In the area of gender representation, the political and cultural elites lay the ground for what should constitute mainstream gender roles and expectations. In the program under study, the dichotomy between the urban and the rural girl is emphasized in a way that serves to maintain and perpetuate the long standing status quo wherein the two sides stand for apparently irreconcilable value systems. To illustrate, in one of the scenes in the eighth episode, an actor falls prey to an act of identity fraud perpetrated by a young girl from the city of Khemisset. The imposter had pretended to have an American nationality in oder to trap him. One of the actors, named 'Lhatrouf', reacted to this incidence by saying "Lhamdou li Allah matalaatsh mirikaniyya. Mlli jina nshoufou lqinaha min l khmissat” “Thank God. She didn't turn out to be American. When we looked into the matter. We found out she was from Khemmisset”. Whether deliberately or inadvertently, this stigmatizing message had triggered numerous sentiments of shock and annoyance from many of this city dwellers in particular, as was displayed on a number of Internet blogs and Facebook pages. In the same vein, Adil Benhamza, a leading MP from Al Istiqlal party, wrote a petition to the High Authority of Audiovisual communication -Haut Autorité de la Communication Audiovisuelle (HACA) in which he demanded the banning of any further rebroadcasting of that episode (Moho, 2014). Reasonably enough, the scene represents an amateurish and blatant violation of the standards laid down by the official Specifications Document (Cahier de Charge) that warns against the dissemination of stereotypical representations of demographic, social and linguistic groups.

First of all, the urban girl Kenza takes on the name of Benani Berrada, which is, socially speaking, a highly prestigious family name traditionally associated with one of the intellectual and wealthy elites of the Moroccan population. On the other hand, the rural girl is assigned the name of Hlima which pertains, in general, to an ordinay social class rated below the urbane and sophisticated sub-population. This contrast becomes so obvious when Kenza speaks with a Fassi vernacular and accent as opposed to Hlima's 'funny' -albeit intriguing- rural accent. The socio-cultural gap between the two parties is further exacerbated when Kenza is portrayed as the civilized and hi-tech-savvy girl compared to her 'uncivilized and mostly 'vulgar' counterpart. Accordingly, the latter is depicted as bizarrely unacquainted with wifi internet connection and is even capable of using a mobile phone appropriately! Nevertheless, her illiteracy does not prevent her from outwitting the young urban stylish project manager by articulating her outrage against the 'industrial invasion' and the imminent contamination of her local community and environment. This image of Hlima as the strident and rebellious girl resonates well with her non-materialistic style and passionate romantic relationship with her loyal but 'aging' lover Bouchaib; 
an unconditional love that was kept in limbo for over 14 years! Notwithstanding her insatiable appetite for success and voracious ambition, Kenza is always the 'loser' who eventually succumbs in her perpetual battle to the 'victorious' local girl. This failure, according to Stafford (2004), is so common in many sit-coms and prime-time shows because "comic characters are flawed. Comedy arises from their inability to do some things or their propensity to attempt the impossible. Classic comedy characters are always failing (in) gloriously” (p. 6).

\section{Values, gender and identity}

In their attempt to reflect mainstream traditional Moroccan cultural gender values, the sit-com draws a rather 'distorted' distinction between masculine and feminine behavioral and character dispositions. As an instance, integrity, honesty and innocence are portrayed as essentially female-oriented values. Man generally represents the pervert and the violent. To illustrate, in one of the episodes, there features a scene in which Latif tortures, both verbally and non-verbally Bouchaib, in stark infringement of the Licensing Obligations Documents of the HACA. Family values, because of their erosion, no longer seem to hold their roles in cementing the social fabric of the Moroccan society as a whole which is pictured as dysfunctional and in sheer decay.

To start with, the conventional sensational theme of 'woman against woman' (Sinclair,1938) is embodied in Hlima's leading efforts to rally support for her 'cause' to protect her village from the danger of malicious urbanization and hence to make the realization of the dream of the young manager come to a total fiasco!. This is even bitterly dramatized when Hlima symbolically rejects everything associated with modernity, technology or fashion. Though they are obliged to live under the same roof, Kenza does not miss out on any opportunity to tease Kenza and ridicule her stylish behavior and 'unspontaneous' way of talking.

The ambitious girl from Casablanca is thus left to fight on her own with little substantial assistance from the central agency or her companion. Most of the village inhabitants wage their unrelenting war against her highway project. She is obviously exhausted, strained and thrust into a 'Man's World'. This myth is recurrent in many episodes as she complains about males who plot and connive to sabotage her career. Surprisingly, these same 'males' repeatedly, but covertly, express their admiration for her strong personality, character, and fine taste.

From a sociological standpoint, the theme of delayed nuptiality runs across the various social layers of demographic categories. That is, it is not only the unemployed and the less qualified that are unable to set up families at an age that reaches the thirties like Hlima and Bouchaib and even the late 
fifties like Ben but the other well-off and more intellectually sophisticated do not equally seem to conceive of 'marriage' as a top priority. The fate of many such young single actors and actresses is reminiscent of the classical imported western movies in which the issue of 'Man without woman' and 'Woman without man' is prevalent. Unsurprisingly, the series does intentionally or unintentionally goes in line with a socio-demographic shift that Morocco is currently undergoing. Statistically speaking, the mean first marriage age for men in 2004 had "changed to 31.2 for men and 26.3 for women - some of the highest rates in the developing world." (Boudarbat \& Ajbilou, 2007). Apparently, personal success and achievement are highlighted as an obsession that brands a mostly 'smart' and individualistic generation. From an agenda setting perspective, and compared to other national outlets at least, 2M station has on several occasions been accused of holding an avant-gardist and catalytic role in both nourishing and promoting Moroccan female emancipation and gender empowerment project. Thus, the representation of female lead characters has shifted "away from creating females as adornment, enticement, or with inclination to romance as the main or exclusive personality trait or motivator [to] the creation of diverse, complicated females who initiate and/or actively participate in their destinies.” (Smith \& Cook, 2008).

Indeed, in line with the new family code (the Moudawana) that saw light in 2004 and which was hailed as a giant breakthrough in Moroccan civil rights, the channel has spared no effort to wage fierce wars against polygamy, violence against women, sexual exploitation, female child labor, early marriage etc. The latter issue in particular has gained huge momentum over the last few years thanks to the ideological rift that polarizes Moroccan liberals with religious conservatives. The strategy of $2 \mathrm{M}$ channel to subvert traditional gender stereotypes is well-documented across many programs, mainly melodramas, series, reality shows, music and artistic programs. 'Kenza F' Douar' series is a good case in point. In addition to the overarching representation of the lead character -Kenza- as independent and powerful, the profile of many other actresses, such as Hlima and Lkhaouda, is colored with more masculine attributes, namely toughness, self-reliance, and stubbornness. They are also pictured as largely less emotional than their male counterparts. The scene in the18th episode in which Hlima speaks out against her mother's decision to allow the marriage of her minor younger sister Rabha is indicative of the program designers' efforts to sensitize viewers, especially the rural and less educated, to the dangers of early marriage.

Nevertheless, the conclusiveness about the existence of a coherent institutional media policy towards gender issues seems to be readily challenged by many analysts. The $22^{\text {nd }}$ episode, for example, features a scene 
in which the village women organize a gathering to protest against the imminent threat of a group of women called 'Laayalat Jayyat' 'Women are coming' who are supposedly coming to the village. Men, from their part do look joyful and celebrate their coming as this would allow them, goes their argument, to have more beautiful women around, and perhaps to marry more! These 'invaders' are but a host of female activists who belong to a feminist movement that bears the name of 'Laayalat Jayyat'. Such a parody does caricature feminist movements in general and undermines the efforts made by such NGOs in areas of health awareness, hygiene sensitization, economic and political empowerment etc.

On the basis of the above discussion and aforementioned findings, we can make the following recommendations. First of all, the national audiovisual strategy needs to be constantly reviewed in order to cater to the demands of a maturing audience. The assumption that hastily-prepared home-produced comic programs will be readily engulfed by gullible consumers in Ramadan is unfounded and utterly fallacious. Chennoufi, a media analyst, points out that "Comedy is a difficult genre, requiring lots of time and research; most of the programs are characterized by amateurism. It is time to give young artists an opportunity to bring new ideas" (View from Fez, 2013). Bitterly disappointed with the low quality of most local programming, many viewers simply decide to veer to other foreign satellite outlets, mostly Arab ones, which present rich and varied menus of unrivalled educational, cultural and amusing programs. From her part, Siham Bahri, a forum commentator, laments the mediocrity of most state tele-visual content in Ramadan and asserts that "shows on the foreign channels are worlds away from those on the domestic channels; from hidden camera shows to sitcoms to made-for-TV films, the quality fluctuates. There are very few home-made programs shown during Ramadan which are good enough.” (Ibid.).

Equally important, incorporating media literacy programs in Moroccan educational curricula is likely to boost the viewers' critical thinking skills and allow them to build up more immune personalities. This will also enable them to develop more tolerance towards the 'other' by accepting multiple views and conceding to different interpretations. In this regard, Pryor and Knupfer (1997) explain that "If we become aware of the stereotypes and teach critical viewing skills to our children, perhaps we will become informed viewers instead of manipulated consumers”.

\section{Conclusion}

Thus far, this paper has sought to examine the underlying implications of gender representations in the prime-time series of 'Kenza $F$ 'Douar' (Kenza in the village) that was broadcast in Ramadan 2014. Our analysis has been partly inspired by the referential study developed by Smith 
and Cook (2008). It has been demonstrated that the gender portrayals aired on this program seem to remarkably resonate with $2 \mathrm{M}$ channel agenda that seeks to effect a mainstreaming of 'popular feminism' backed by the 'lobbying' of a powerful board of directors. The series of 'Kenza F 'Douar' thus finely subscribes to a whole string of highly-rated former 'Ramadan serial comedies', just like Rbib, Lalla Fatima and Bnat Lalla Mnnana, that have won the hearts of millions of avid Moroccan viewers for over a decade. The wide array of incoherent discourses latent in the program on what constitutes femininity and masculinity, sexuality, gender role distribution, and power relationships all point to the absence of a systematic, coherent, well-grounded and long-term media strategy.

Overall, Moroccan media policy-makers should thus cease to regard audiences as a mere commodity. Profit making attitudes should not override the essential raison d'être of TV as an essential tool of public service. (McQuail, 1992). Zaid (2014) also supports this attitude by clarifying that "Public service broadcasting implies that programming decisions should never reflect the interests of small groups but rather the interest of the population as a whole.”

\section{References:}

1. Artz, N., \& Venkatesh, A. (1991). Gender Representation in Advertising in Advances in Consumer Research. 18, 618-623. Retrieved January 28, 2015 from: http://acrwebsite.org/volumes/7225/volumes/v18/NA-18

2. Boudarbat. B. \& Ajbilou. A. (2007). Youth Exclusion in Morocco: Context, Consequences, and Policies Middle East Youth Initiative Working Paper, 5. Wolfensohn center for development. Dubai School of Government.

3. Entman, R. M., \& Rojecki, A. (2000). The Black Image in the White Mind: Media and Race in America. Chicago: University of Chicago Press.

4. Frey, L., Botan, C., \& Kreps, G. (1999). Investigating communication: An introduction to research methods. (2nd ed.) Boston: Allyn \& Bacon.

5. Gauntlett, D. (2008). Media, gender and identity: An introduction. Routledge. Gerbner, G., Gross, L., Morgan, M., \& Signorelli, N. (1986). Living with television: The dynamics of the cultivation process. In J. Bryant \& D. Zillman (Eds.), Perspectives on media effects (pp. 17-40). Hillsdale, NJ: Lawrence Erlbaum.

6. Gerbner, G., Gross, L., Morgan, M., Signorielli, N., \& Shanahan, J. (1994). Growing up with television: The Cultivation processes. In J. Bryant and D. Zillmann (Eds.), Media effects: Advances in theory 
and research (pp. 43 - 67). Mahwah, NJ: Lawrence Erlbaum Associates.

7. Goldberg L., Lang. C, \& Biasutti. M. (2005). Gender and Poverty Project: Gender Analysis Tools. Status of Women, Canada. Retrieved March 9, 2016 from: http://ywcacanada.ca/data/research_docs/00000370.pdf

8. Habermas, J. (1992). “Further Reflections on the Public Sphere”. in Calhoun, C. (ed.) Habermas and the Public Sphere. pp. 421-461. Cambridge, MA: MIT Press.

9. Haut-commissariat au Plan du Maroc (HCP). (2015). « La femme marocaine en chiffres, tendances d'évolution des caractéristiques démographiques et socioprofessionnelles.» Retrieved October 20, 2015 from: http://www.hcp.ma/Direction-de-la-statistique_a716.html.

10. Jamieson, K. (1993). Dirty Politics: Deception, Distraction, and Democracy. New York: Oxford University Press.

11. Kaiser Family Foundation. (2010). Generation M2: Media in the lives of 8-to 18-yearolds.

12. Retrieved October 24, 2015: http://www.kff.org/entmedia/upload/mh012010 presentL.pdf.

13. Lublin, D. (1997b). The Paradox of Representation: Racial Gerrymandering and Minority Interests in Congress. Princeton, NJ: Princeton University Press.

14. McQuail, D. (2003). Media Accountability and Freedom of Publication. Oxford: Oxford University Press.

15. Moho, F. (2014). "Kenza F' Douar": Un Cadre De L'istiqlal Dénonce Un Dérapage.Retrieved August 15, 2014 from: http://fr.le360.ma/medias/kenza-f-douar-un-cadre-de-listiqlaldenonce-un-derapage

16. N.A. (2013). Ramadan Diary: Nine days into the fast and the talk turns to taxis and television. In: The View from Fez: Retrieved December 14 , 2014 from:http://riadzany.blogspot.com/2013/07/ramadan-diary-nine-daysinto-fast-and.html

17. Pergola, S. D. (2012). World Jewish Population. Current Jewish Population Reports, 7. North American Jewish Data Bank.

18. Potter, W. J., \& Chang, I. K. (1990). Television exposure measures and the cultivation hypothesis. Journal of Applied Communication Research, 27, 258-284.

19. Pryor. D. \& Knupfer. N. (1997). Gender Stereotypes and Selling Techniques in Television Advertising: Effects on Society. Retrieved January 14, 2013 from: http://files.eric.ed.gov/fulltext/ED409861.pdf Rössler, P., \& Brosius, H. (2001). Do talk-shows cultivate 
adolescents' views of the world? A prolonged-exposure experiment. Journal of Communication, 51(1), 143-163.

20. Sinclair, R. B. (Producer), \& Chodorov. E. (Director). (1938). Woman against Woman [Motion picture]. United States: metroGoldwyn-Mayer.

21. Smith, S. L., \& Cook, C. A. (2008). Gender Stereotypes: An Analysis of Popular Films and TV. Retrieved March 4, 2014 from: http://thegeenadavisinstitute.org/downloads/GDIGM_Gender_Stereot ypes

22. SOREAD 2M. (Producer). (2014). Kenza F'Douar. [Television series]. Morocco: 2M TV.

23. Stafford, R. (2004).TV Sitcoms and Gender. Retrieved May 26, 2014 from:

24. http://www.media-diversity.org/en/additional-files/documents/bstudies-pdf

25. TelQuel. (2014).2M écrase Al Oula le premier jour du Ramadan. Retrieved July 19, 2014 from:http://telquel.ma/2014/07/02/2mecrase-al-oula-premier-jour-ramadan

26. Zaid, B. (2014). Quantitative content analysis of Moroccan public service television. Global Media Journal. Arabian Edition, Fall/Spring 2013-2014 (3), 3-19. 